\title{
The Effect of Endogenous Modulator Endobain E on NMDA Receptor Is Interfered by $\mathrm{Zn}^{2+}$ but Is Independent of Modulation by Spermidine
}

\author{
A. Reinés, ${ }^{1,2}$ S. Zárate, ${ }^{1}$ C. Peña, ${ }^{3}$ and G. Rodríguez de Lores Arnaiz ${ }^{1,2,3}$
}

(Accepted October 27, 2003)

\begin{abstract}
A brain endogenous factor, termed endobain $\mathrm{E}$, allosterically decreases $\left[{ }^{3} \mathrm{H}\right]$ dizocilpine binding to NMDA receptor. Such effect depends on receptor activation by the coagonists glutamate and glycine and is interfered by channel blockers, suggesting its interaction with the inner surface of the associated channel. To further analyze endobain E effect on NMDA receptor, in the current study competitive $\left[{ }^{3} \mathrm{H}\right]$ dizocilpine binding assays to brain membranes were performed with $\mathrm{Zn}^{2+}$ to block the associated channel, as well as with spermidine (SPD), which exerts positive allosteric modulation of NMDA receptor. Partially or nonadditive effects on $\left[{ }^{3} \mathrm{H}\right]$ dizocilpine binding were recorded, respectively, in the presence of endobain $\mathrm{E}$ at a concentration that inhibits binding $25 \%$ plus $\mathrm{IC}_{25}$ $\mathrm{Zn}^{2+}$ or endobain $\mathrm{E}$ at a concentration that inhibits binding $50 \%$ plus $\mathrm{IC}_{50} \mathrm{Zn}^{2+}$. With an endobain E concentration that decreases $25 \%$ ligand binding, SPD potentiated binding over a wide concentration range but failed to modify endobain E effect. Similarly, $\left[{ }^{3} \mathrm{H}\right]$ dizocilpine binding reduction over a wide endobain E concentration range remained unaltered by high SPD concentrations. Additive effects were observed with endobain $\mathrm{E}$ at a concentration that decreases binding $25 \%$ plus $\mathrm{IC}_{25}$ SPD site antagonists arcaine or ifenprodil. $\mathrm{Zn}^{2+}$ experiments indicated that endobain $\mathrm{E}$ effect is interfered by channel blockade produced by this ion. Although endobain E effect is dependent on NMDA receptor activation by glutamate and glycine, it proves independent of the positive modulation exerted by SPD. Thus the endogenous modulator seems not to interact at NMDA receptor polyamine site, favoring the hypothesis that endobain E binds inside the associated channel.
\end{abstract}

KEY WORDS: NMDA receptor; spermidine; polyamine site; endobain; dizocilpine binding; endogenous modulator; receptor modulation; zinc ion.

\section{INTRODUCTION}

NMDA receptor is a subclass of glutamatergic ionotropic receptor sensitive to the exogenous agonist $\mathrm{N}$-methyl-D-aspartic acid (NMDA). This receptor is an ionophore complex consisting of at least four different domains: an ion channel domain permeable to

\footnotetext{
${ }^{1}$ Instituto de Biología Celular y Neurociencias "Prof. E. De Robertis," Facultad de Medicina.

${ }^{2}$ Cátedra de Farmacología, Universidad de Buenos Aires, Buenos Aires, Argentina.

${ }^{3}$ IQUIFIB-CONICET, Facultad de Farmacia y Bioquímica, Universidad de Buenos Aires, Buenos Aires, Argentina.
}

$\mathrm{Ca}^{2+}$; an NMDA recognition domain with high affinity for L-glutamic acid; a glycine recognition domain insensitive to strychnine; and a polyamine recognition domain. Coagonists glutamate and glycine activate the NMDA receptor, leading to channel opening followed by intracellular $\mathrm{Ca}^{2+}$ increase. Substances such as dizocilpine, ketamine, and $\mathrm{Mg}^{2+}$ block $\mathrm{Ca}^{2+}$ influx by binding inside the receptor associated channel (1).

\footnotetext{
${ }^{3}$ Address reprint requests to: Dr. Georgina Rodríguez de Lores Arnaiz, Instituto de Biología Celular y Neurociencias "Prof. E. De Robertis," Facultad de Medicina, Universidad de Buenos Aires, Paraguay 2155, 1121-Buenos Aires, Argentina. Fax: 54-11-4508-3645 or 4964-8274; E-mail: grodrig@ffyb.uba.ar
} 
The NMDA receptor is modulated by several endogenous substances, evidencing the importance of fine-tuning for this receptor function (2-4). In addition, many of the allosteric modulators provide tonic inhibition under physiological conditions, suggesting that allosteric regulation can protect against the damage resulting from NMDA receptor overactivation (2). One example is NMDA receptor inhibition by $\mathrm{Zn}^{2+}$ through both voltage-dependent and voltage-independent mechanisms $(5,6)$. On the other hand, polyamines are positive allosteric modulators of NMDA receptor able to stimulate its function by favoring channel opening in the presence of receptor coagonists glutamate and glycine (2).

The isolation of an endogenous brain $\mathrm{Na}^{+}, \mathrm{K}^{+}-$ ATPase inhibitor, termed endobain E, which shares several biological properties with ouabain, such as highaffinity $\left[{ }^{3} \mathrm{H}\right]$ ouabain binding blockade (7) and norepinephrine release (8), has been described. Endobain E has low $\mathrm{Mr}(<1000)$, is highly hydrophilic, nonlipidic, nonpeptidic, and anionic $(9,10)$.

It was observed that endobain E allosterically decreases $\left[{ }^{3} \mathrm{H}\right]$ dizocilpine binding to NMDA receptor, an effect dependent on receptor activation by glutamate and glycine. As endobain $\mathrm{E}$ effect is interfered by ketamine and $\mathrm{Mg}^{2+}$, the suggestion that this factor modulates NMDA receptor, most likely by binding inside the associated channel, has been advanced $(11,12)$.

The aim of the present study was to evaluate the influence of $\mathrm{Zn}^{2+}$ and polyamine spermidine (SPD), two NMDA receptor modulators, on $\left[{ }^{3} \mathrm{H}\right]$ dizocilpine binding reduction by endobain $\mathrm{E}$.

\section{EXPERIMENTAL PROCEDURE}

Animals. Male Wistar rats, 130-160 g weight, were used. All studies described were conducted in accordance with the Guide for Care and Use of Laboratory Animals provided by the National Institutes of Health, USA. Reagents were analytical grade. $\mathrm{ZnCl}_{2}$ was from Merck (Darmstadt, Germany); Sephadex G-10, arcaine, ifenprodil, SPD, and 2,5-diphenyloxazol (PPO) were from Sigma Chemical Co. (St. Louis, MO, USA); Sephadex G-50 (fine grade) was from Pharmacia Fine Chemicals (Uppsala, Sweden); unlabeled dizocilpine maleate [(+)-MK-801 hydrogen maleate, (+)-5-methyl-10,11-dihydro-5H-dibenzo[a,d]cyclohepten-5,10-imine hydrogen maleate], were from Research Biochemicals International, Inc. (Natick, MA, USA); $\left[{ }^{3} \mathrm{H}\right]$ dizocilpine, with a specific radioactivity of $884.3 \mathrm{GBq} / \mathrm{M} \times 10^{-3}$, was purchased from New England Nuclear, Du Pont (Boston, MA, USA).

Preparation of Crude Cerebral Cortex Membranes. Cerebral cortices from five rats were harvested, dropped into cold $0.32 \mathrm{M}$ sucrose, and processed following Ogita and Yoneda (13), with modifications. Tissues were homogenized at $10 \%(\mathrm{w} / \mathrm{v}$, original tissue) for two 1-min periods in $0.32 \mathrm{M}$ sucrose (neutralized to $\mathrm{pH} 7$ with Tris base solution) using a Teflon glass homogenizer of the Potter-Elvehjem type, and centrifuged at $900 \times g$ for $10 \mathrm{~min}$. The resultant supernatants were ultracentrifuged at $100,000 \times g$ for $30 \mathrm{~min}$ in a 70.1 rotor of an L8-Beckman ultracentrifuge. Pellets were washed by resuspension in redistilled water at $10 \%$ (w/v, original tissue) and spun down $(100,000 \times g$ for $30 \mathrm{~min})$. This process was then repeated twice. Pellets were resuspended in $50 \mathrm{mM}$ Tris- $\mathrm{HCl}$ buffer, $\mathrm{pH} 7.4$, at $10 \%$ (w/v, original tissue), incubated with gentle stirring at $23^{\circ} \mathrm{C}$ for $30 \mathrm{~min}$, spun down at $100,000 \times \mathrm{g}$ for $30 \mathrm{~min}$ and stored at $-70^{\circ} \mathrm{C}$ after resuspension in $0.32 \mathrm{M}$ sucrose; hereafter, they are termed "resuspended" membranes.

Membrane Treatment. On the day of the binding assay, membranes stored at $-70^{\circ} \mathrm{C}$ after resuspension in sucrose were thawed and spun down at $100,000 \times g$ for $30 \mathrm{~min}$. Pellets were washed succesively by resuspension in redistilled water (at $10 \%, \mathrm{w} / \mathrm{v}$ ) and in $50 \mathrm{mM}$ Tris$\mathrm{HCl}$ buffer, $\mathrm{pH} 7.4$, and centrifuged at $100,000 \times g$ for $30 \mathrm{~min}$. Resultant pellets were homogenized in water to reach a final concentration of $10 \mathrm{mg}$ protein $/ \mathrm{ml}$ and processed for ligand binding.

To study NMDA receptor polyamine site, membranes were treated with Triton X-100, according to Yoneda et al. (14), with modifications. Membrane samples were unfrozen, spun down at $100,000 \times g$ for $30 \mathrm{~min}$ and pellets resuspended in $0.08 \%$ Triton X-100 at $0.32 \mathrm{mg}$ protein $/ \mathrm{ml}$, and incubated with gentle stirring at $0-4^{\circ} \mathrm{C}$ for $10 \mathrm{~min}$. Treatment was stopped by centrifugation at $100,000 \times g$ for $30 \mathrm{~min}$. Resultant pellets were washed twice by resuspension at $10 \%(\mathrm{w} / \mathrm{v})$ in $50 \mathrm{mM}$ Tris- $\mathrm{HCl}$ buffer, $\mathrm{pH} 7.4$, and centrifuged at $100,000 \times g$ for $30 \mathrm{~min}$; hereafter, they are termed "Triton-treated" membranes. Resultant pellets were homogenized in water to reach a final concentration of $4 \mathrm{mg}$ protein $/ \mathrm{ml}$ and processed for ligand binding.

Preparation of II-E Fraction (Endobain E). Peak I and II fractions from rat cerebral cortex were prepared as previously described $(9,15)$. Thus, for each preparation, cerebral cortices from five rats were pooled, homogenized at $25 \%(\mathrm{w} / \mathrm{v})$ in redistilled water, and centrifuged at $100,000 \times g$ for $30 \mathrm{~min}$ at $4^{\circ} \mathrm{C}$ in a 70.1 rotor of an L8-Beckman ultracentrifuge. A 5-ml supernatant sample (brain-soluble fraction) was taken to $\mathrm{pH} 7.4$ with $0.1 \mathrm{M} \mathrm{NH}_{4} \mathrm{HCO}_{3}$ and loaded on a Sephadex G-10 column $(1 \times 20 \mathrm{~cm})$ and a single $11 \mathrm{ml}$ fraction collected. This filtrate was then applied to a column packed with Sephadex G-50 $(1.8 \times 25 \mathrm{~cm})$. For gel equilibration and elution, $0.01 \mathrm{M} \mathrm{NH}_{4} \mathrm{HCO}_{3}$ was used. Fractions of $1.4 \mathrm{ml}$ each at a flow rate of $0.3 \mathrm{ml} / \mathrm{min}$ were collected in an Gilson Fraction Collector 202. The absorbance profile was recorded at $280 \mathrm{~nm}$. Peaks I and II were made up with the fractions presenting maximal UV absorbance. Peak I was made up with fractions 19-23 but not used in this study; peak II was made up with fractions $48-52$. Peak II was adjusted to $\mathrm{pH} 2.0$ with $2 \mathrm{M} \mathrm{HCl}$, lyophilized, and stored at $-20^{\circ} \mathrm{C}$. The following day, peak II samples were processed by anionic exchange HPLC on a Synchropak AX-300 column, $250 \times 4.6$ mm (Synchrom Inc., Lafayette, IN, USA) and eluted at a flow rate of $0.5 \mathrm{ml}$ per min with a 20-min gradient from 0.001 to $0.010 \mathrm{M} \mathrm{NH}_{4} \mathrm{HCO}_{3}$ to separate fractions II-A to II-H. Fractions were collected by monitoring of absorbance curves at $230 \mathrm{~nm}$; II-E was collected at 12-13 min, then lyophilized, and used within 20 days (9). Lyophilized II-E samples were dissolved in $0.006 \mathrm{M} \mathrm{HCl}$ (at a concentration of $4 \mathrm{mg}$ original tissue per $\mu \mathrm{l}$ ) and immediately before assay neutralized with $0.2 \mathrm{M}$ Tris base solution. Hereafter, II-E fraction is termed endobain E.

$\left[{ }^{3} \mathrm{H}\right]$ Dizocilpine Binding Assay. Ligand binding to membranes was performed according to Yoneda et al. (14), with modifications. Triplicate membrane aliquots were processed according to current techniques $(14,16)$. Aliquots of resuspended membranes or Triton X-100 treated membranes were incubated in $50 \mathrm{mM}$ Tris- $\mathrm{HCl}$ buffer, $\mathrm{pH} 7.4(0.25 \mathrm{ml}$ final volume), at $30^{\circ} \mathrm{C}$ for $30 \mathrm{~min}$ in the presence of $4 \mathrm{nM}$ $\left[{ }^{3} \mathrm{H}\right]$ dizocilpine, $1 \times 10^{-5} \mathrm{M}$ glutamate and $1 \times 10^{-8} \mathrm{M}$ glycine. Protein concentration during incubation (in milligrams per milliliter) was $0.40-0.80$ or $0.16-0.30$ for resuspended and Triton X-100 treated membranes, respectively. When specified, incubation proceeded in the 
presence of SPD, polyamine site antagonists arcaine or ifenprodil, $\mathrm{Zn}^{2+}$ and/or endobain E. In each experiment, samples containing $100 \mu \mathrm{M}$ unlabeled (+)-dizocilpine were processed to determine nonspecific binding, which attained $10 \%-17 \%$ of total binding. Incubation was stopped with $3 \mathrm{ml}$ cold $50 \mathrm{mM}$ Tris- $\mathrm{HCl}$ buffer, $\mathrm{pH} 7.4$, and samples vacuum-filtered through Whatman GF/B glass disks. Filters were rinsed twice with $3 \mathrm{ml}$ of ice-cold buffer and retained radioactivity measured in a liquid scintillation spectrometer. As scintillator solution, $0.4 \% \mathrm{PPO}$ in toluene was employed.

Protein Measurement. Protein was determined by the method of Lowry et al. (17) using bovine serum albumin as standard.

Data Analysis. Data are presented as mean values \pm SD of $n$ experiments. When appropriate, statistical significance of difference has been assessed by two-tailed Student's t test for unpaired samples. A probability level of $\mathrm{P}<.05$ was considered significant.

\section{RESULTS}

Basal $\left[{ }^{3} \mathrm{H}\right]$ dizocilpine binding was $603 \pm 148$ and $1632 \pm 221 \mathrm{fM} / \mathrm{mg}$ protein in resuspended and Triton $\mathrm{X}-100-$ treated membranes, respectively.

\section{Endobain E Effect on $\left[{ }^{3} \mathrm{H}\right]$ Dizocilpine Binding in the Presence of Zinc ion}

Resuspended membranes were incubated with $4 \mathrm{nM}$ $\left[{ }^{3} \mathrm{H}\right]$ dizocilpine, $1 \times 10^{-5} \mathrm{M}$ glutamate plus $1 \times 10^{-8} \mathrm{M}$

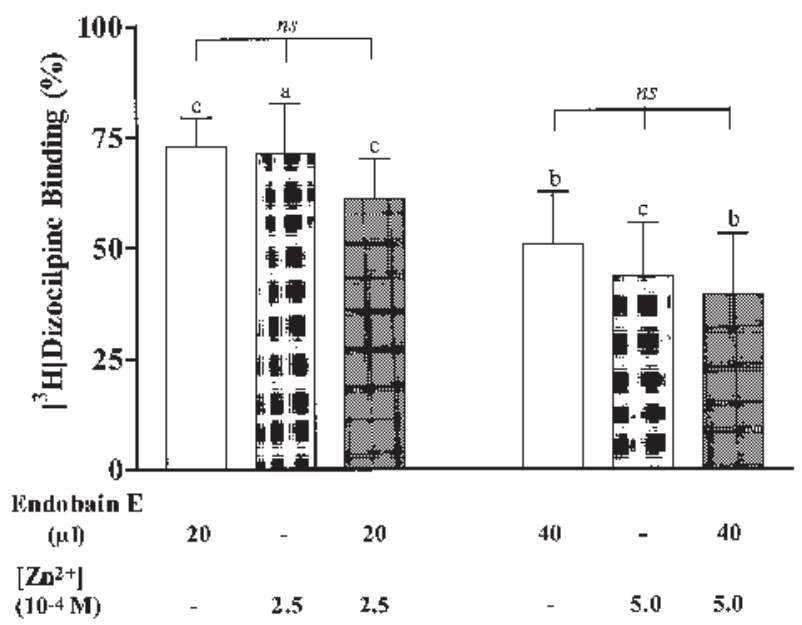

Fig. 1. The effect of endobain $\mathrm{E}$ on $\left[{ }^{3} \mathrm{H}\right]$ dizocilpine binding to NMDA receptor in the presence of $\mathrm{Zn}^{2+}$. Resuspended membranes were incubated with $4 \mathrm{nM}\left[{ }^{3} \mathrm{H}\right]$ dizocilpine, $1 \times 10^{-5} \mathrm{M}$ glutamate plus $1 \times$ $10^{-8} \mathrm{M}$ glycine, with or without $2.5 \times 10^{-4}$ or $5 \times 10^{-4} \mathrm{M} \mathrm{Zn}^{2+}$, in the absence or presence of endobain $\mathrm{E}(1 \mu \mathrm{l}$ equivalent to $4 \mathrm{mg}$ original tissue). Results are expressed as percentage $\left[{ }^{3} \mathrm{H}\right]$ dizocilpine binding (mean $\pm \mathrm{SD} ; \mathrm{n}=4-8$ ) taking as $100 \%$ values obtained without additions. ${ }^{\mathrm{a}} \mathrm{P}<.05$; ${ }^{\mathrm{b}} \mathrm{P}<.01 ;{ }^{\mathrm{c}} \mathrm{P}<.001$ versus corresponding control without $\mathrm{Zn}^{2+}$ or endobain E, by two-tailed Student's $\mathrm{t}$ test for unpaired samples. ns, nonsignificant differences between bars, by two-tailed Student's t-test for unpaired samples. glycine, with or without 2.5 or $5.0 \times 10^{-4} \mathrm{M} \mathrm{Zn}^{2+}$ and/or endobain $\mathrm{E}$ (equivalent to 80 or $160 \mathrm{mg}$ original tissue). In a condition in which $\mathrm{Zn}^{2+}$ and endobain $\mathrm{E}$ individually decreased 25\% ligand binding, 35\% binding reduction was recorded when both substances were present together, indicating a partially additive effect. In the simultaneous presence of endobain $\mathrm{E}$ and $\mathrm{Zn}^{2+}$ at concentrations that separately decreased binding roughly $50 \%$, only $50 \%$ binding reduction was attained indicating a nonadditive effect (Fig. 1).

\section{$\left[{ }^{3} \mathrm{H}\right]$ Dizocilpine Binding in the Presence of Variable SPD or Endobain E Concentrations}

Triton X-100-treated membranes were incubated with $4 \mathrm{nM}\left[{ }^{3} \mathrm{H}\right]$ dizocilpine, $1 \times 10^{-5} \mathrm{M}$ glutamate and $1 \times 10^{-8} \mathrm{M}$ glycine, $1 \times 10^{-8} \mathrm{M}-1 \times 10^{-2} \mathrm{M}$ SPD, in the absence or presence of a fixed endobain $\mathrm{E}$ concentration. As expected, ligand binding was enhanced by polyamine addition in a concentration-dependent manner, reaching approximately $160 \%$ with $1 \mathrm{mM}$ SPD. Results indicated that the presence of endobain $\mathrm{E}$ (equivalent to $80 \mathrm{mg}$ original tissue) decreased ligand binding

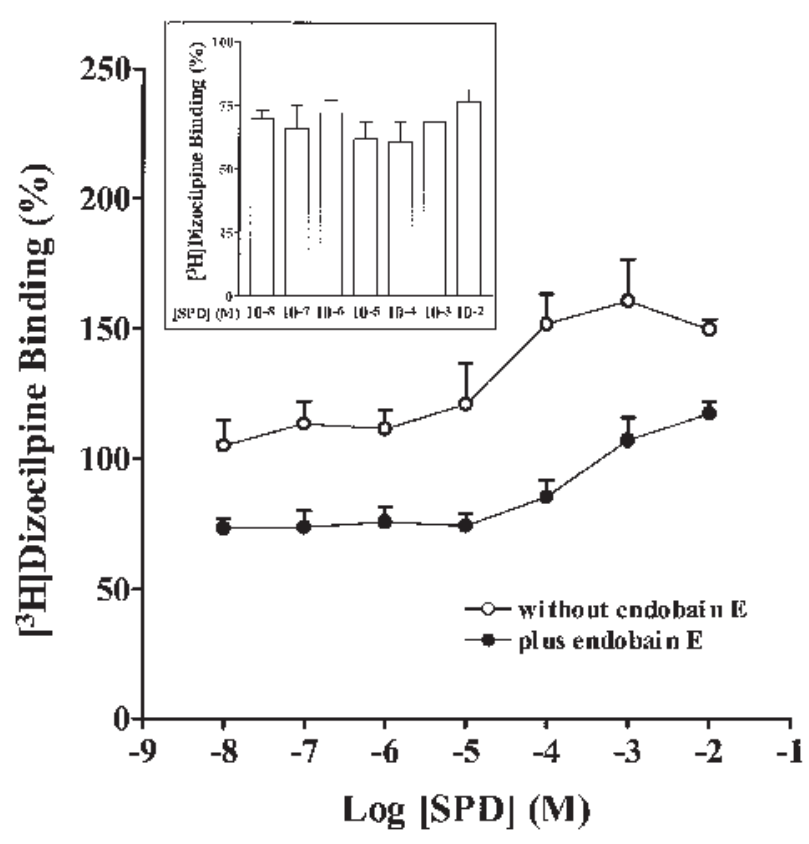

Fig. 2. The effect of endobain $\mathrm{E}$ on $\left[{ }^{3} \mathrm{H}\right]$ dizocilpine binding to NMDA receptor in the presence of several spermidine (SPD) concentrations. Triton X-100-treated membranes were incubated with $4 \mathrm{nM}\left[{ }^{3} \mathrm{H}\right]$ dizocilpine, $1 \times 10^{-5} \mathrm{M}$ glutamate plus $1 \times 10^{-8} \mathrm{M}$ glycine, with or without $1 \times 10^{-8}-1 \times 10^{-2} \mathrm{M} \mathrm{SPD}$, in the absence or presence of endobain $\mathrm{E}$ (equivalent to $80 \mathrm{mg}$ original tissue). Results are expressed as percentage $\left[{ }^{3} \mathrm{H}\right]$ dizocilpine binding (mean $\pm \mathrm{SD} ; \mathrm{n}=3-5$ ) taking as $100 \%$ values obtained without SPD or endobain E addition. Inset, results of binding in the presence of endobain $\mathrm{E}$ versus control for each SPD concentration. 
throughout and that the endogenous modulator failed to alter $\left[{ }^{3} \mathrm{H}\right]$ dizocilpine binding stimulation by SPD (Fig. 2). The extent of endobain $\mathrm{E}$ effect was independent of the SPD concentration employed (Fig. 2, inset).

To further study SPD plus endobain E effects, Triton $\mathrm{X}-100$-treated membranes were incubated with $4 \mathrm{nM}$ $\left[{ }^{3} \mathrm{H}\right]$ dizocilpine, $1 \times 10^{-5} \mathrm{M}$ glutamate and $1 \times 10^{-8} \mathrm{M}$ glycine, with or without $1 \times 10^{-3} \mathrm{M}$ SPD and variable endobain E concentrations (equivalent to 4-360 mg original tissue). Findings confirm previous observations indicating that endobain $\mathrm{E}$ decreased ligand binding in a concentration-dependent manner (11) and showed that $1 \mathrm{mM}$ SPD failed to alter endobain E effect throughout (Fig. 3).

\section{Endobain E Effect on $\left[{ }^{3} \mathrm{H}\right]$ Dizocilpine Binding in the Presence of Polyamine Site Antagonists}

Triton X-100-treated membranes were incubated with $4 \mathrm{nM}\left[{ }^{3} \mathrm{H}\right]$ dizocilpine, $1 \times 10^{-5} \mathrm{M}$ glutamate plus $1 \times 10^{-8} \mathrm{M}$ glycine and $1 \times 10^{-3} \mathrm{M}$ SPD, with or without $1 \times 10^{-4} \mathrm{M}$ competitive polyamine site antagonist arcaine and/or endobain $\mathrm{E}$ (equivalent to $80 \mathrm{mg}$ original tissue). In the presence of endobain $\mathrm{E}$ at a concentration that alone inhibited roughly $30 \%$ ligand binding, $1 \times$ $10^{-4} \mathrm{M}$ arcaine, which alone decreased $20 \%\left[{ }^{3} \mathrm{H}\right]$ dizocilpine binding, approximately $45 \%$ binding reduction was recorded, indicating an additive effect (Fig. 4A). $\left[{ }^{3} \mathrm{H}\right]$ dizocilpine binding to Triton X-100-treated membranes

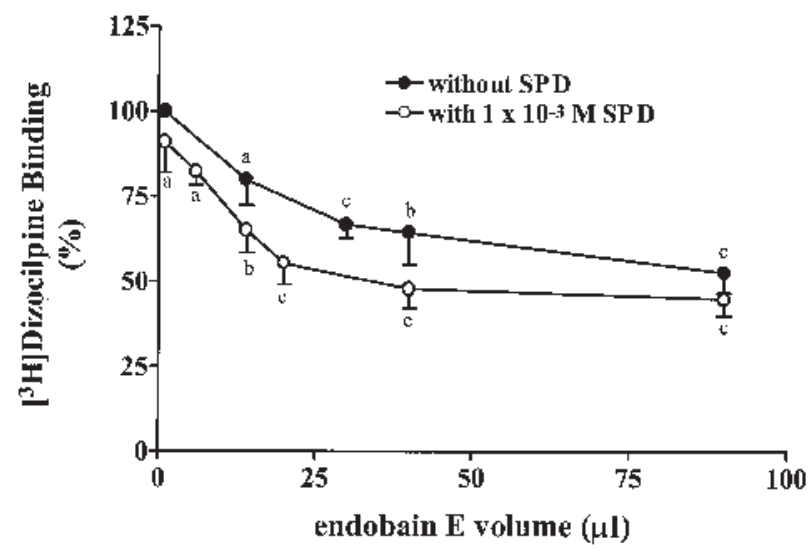

Fig. 3. The effect of variable endobain $\mathrm{E}$ concentration on $\left[{ }^{3} \mathrm{H}\right]$ dizocilpine binding in the presence of spermidine (SPD). Triton $\mathrm{X}-100-$ treated membranes were incubated with $4 \mathrm{nM}\left[{ }^{3} \mathrm{H}\right]$ dizocilpine, $1 \times 10^{-5} \mathrm{M}$ glutamate plus $1 \times 10^{-8} \mathrm{M}$ glycine, with or without $1 \times$ $10^{-3} \mathrm{M}$ SPD, in the absence or presence of endobain $\mathrm{E}(1 \mu \mathrm{l}$ equivalent to $4 \mathrm{mg}$ original tissue). Results are expressed as percentage $\left[{ }^{3} \mathrm{H}\right]$ dizocilpine binding (mean $\pm \mathrm{SD} ; \mathrm{n}=3-4$ ) taking as $100 \%$ control values recorded for each incubation medium. ${ }^{\text {ap }}<.05$; ${ }^{\text {b }} \mathrm{P}<.01$; ${ }^{\mathrm{c}} \mathrm{P}<.001$ versus corresponding control recorded in the absence of endobain E, by two-tailed Student's t test.

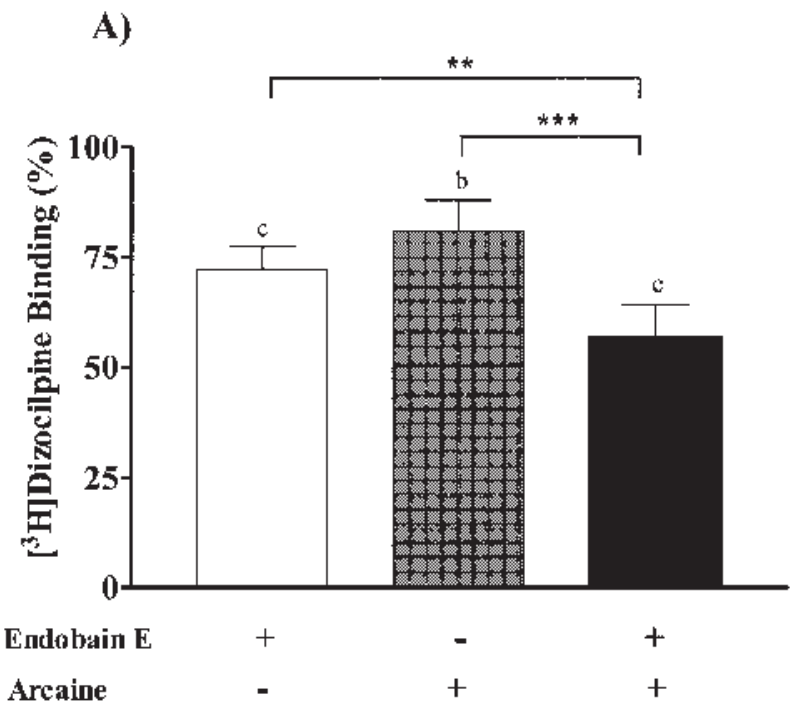

B)

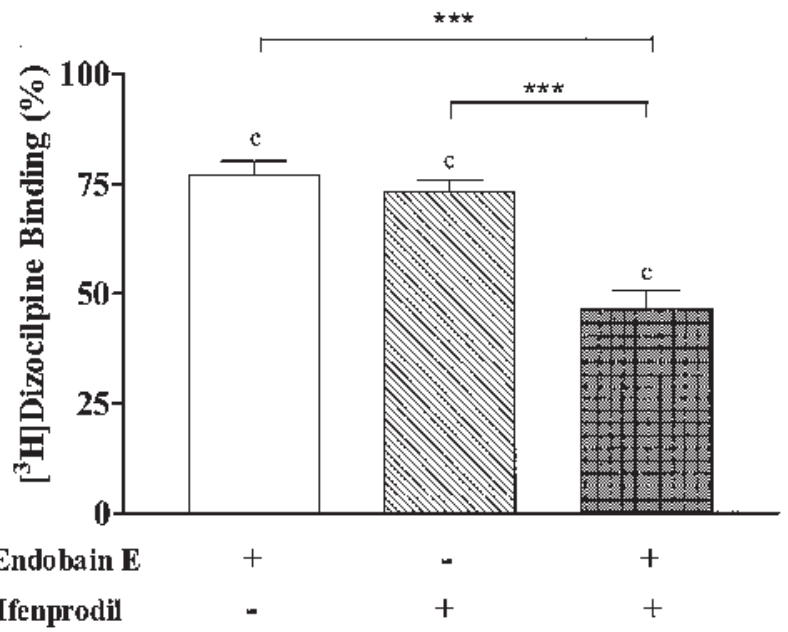

Fig. 4. The effect of endobain $\mathrm{E}$ on $\left[{ }^{3} \mathrm{H}\right]$ dizocilpine binding in the presence of arcaine or ifenprodil, competitive and noncompetitive antagonists for NMDA polyamine site, respectively. Triton $\mathrm{X}$-100-treated membranes were incubated with $4 \mathrm{nM}\left[{ }^{3} \mathrm{H}\right]$ dizocilpine, $1 \times 10^{-5} \mathrm{M}$ glutamate plus $1 \times 10^{-8} \mathrm{M}$ glucine, $1 \times 10^{-3} \mathrm{M} \mathrm{SPD}$, with or without endobain $\mathrm{E}$ (equivalent to $80 \mathrm{mg}$ original tissue), $1 \times$ $10^{-4} \mathrm{M}$ arcaine (A) or $1 \times 10^{-5} \mathrm{M}$ ifenprodil (B). Results are expressed as percentage $\left[{ }^{3} \mathrm{H}\right]$ dizocilpine binding (mean $\pm \mathrm{SD} ; \mathrm{n}=$ $3-5$ ) taking as $100 \%$ control values for each incubation medium in the absence of additions. ${ }^{\mathrm{b}} \mathrm{P}<.01$; ${ }^{\mathrm{c}} \mathrm{P}<.001$ versus corresponding control without antagonist or endobain E, by two-tailed Student's t test for unpaired samples. ${ }^{* * \mathrm{P}}<.01$; $* * * \mathrm{P}<.001$ between bars, by two-tailed Student's t test for unpaired samples.

was also studied in the presence of ifenprodil, a noncompetitive antagonist of polyamine site. Assays were performed in a medium containing $4 \mathrm{nM}\left[{ }^{3} \mathrm{H}\right]$ dizocilpine, $1 \times$ $10^{-5} \mathrm{M}$ glutamate plus $1 \times 10^{-8} \mathrm{M}$ glycine, $1 \times 10^{-3} \mathrm{M}$ $\mathrm{SPD}, 1 \times 10^{-5} \mathrm{M}$ ifenprodil and/or endobain $\mathrm{E}$ (equivalent to $80 \mathrm{mg}$ original tissue). The simultaneous presence 
of endobain $\mathrm{E}$ and ifenprodil, which independently led to $25 \%$ reduction in binding, resulted in 50\% binding decrease, indicating an additive effect (Fig. 4B).

\section{DISCUSSION}

In the present study we analyzed the influence of $\mathrm{Zn}^{2+}$ and polyamine SPD on the decrease in $\left[{ }^{3} \mathrm{H}\right]$ dizocilpine binding to NMDA receptor exerted by a brain endogenous factor termed endobain E. Results showed that endobain $\mathrm{E}$ effect is interfered by $\mathrm{Zn}^{2+}$ (at concentrations known to block the receptor associated channel) but not by SPD (at concentrations known to exert positive allosteric receptor modulation), ruling out endobain $\mathrm{E}$ potential interaction at polyamine site and suggesting that the endogenous factor most likely binds inside the receptor channel, in agreement with findings showing that ketamine and $\mathrm{Mg}^{2+}$, which bind inside the channel, also interfere with the effect of this endogenous modulator (12).

Zinc ion modulates NMDA receptor by acting at two different sites, one outside the membrane field and the other inside the associated channel. At concentrations as low as $1-10 \mu \mathrm{M}, \mathrm{Zn}^{2+}$ binds to the first site leading to a decrease in channel opening frequency, a voltageindependent effect. At higher concentrations $(100 \mu \mathrm{M})$, $\mathrm{Zn}^{2+}$ additionally binds to the second site, producing channel blockade (18). To study the influence of channel blockade by $\mathrm{Zn}^{2+}$ on NMDA receptor modulation by endobain $\mathrm{E}$, competitive $\left[{ }^{3} \mathrm{H}\right]$ dizocilpine binding experiments with different concentrations of endobain $\mathrm{E}$ and $\mathrm{Zn}^{2+}$ were carried out. The simultaneous presence of endobain $\mathrm{E}$ plus $\mathrm{Zn}^{2+}$ (at concentrations known to exert voltage-dependent receptor blockade) produced a nonadditive effect, suggesting that by binding inside the NMDA receptor associated channel this ion interferes with endobain $\mathrm{E}$ effect. This result is in line with the finding that endobain $\mathrm{E}$ effect on $\left[{ }^{3} \mathrm{H}\right]$ dizocilpine binding to NMDA receptor is dependent on receptor activation by glutamate and glycine and that endobain $\mathrm{E}$ effect is interfered by ketamine and $\mathrm{Mg}^{2+}$ (12).

Polyamines are positive allosteric modulators of NMDA receptor (2), and potentiate $\left[{ }^{3} \mathrm{H}\right]$ dizocilpine binding in Triton X-100-treated membranes, an effect more sensitive in the presence of glutamate and glycine $(13,14)$. $\left[{ }^{3} \mathrm{H}\right]$ dizocilpine binding is potentiated by polyamines by binding to a site close but different to coagonist glutamate and glycine sites, in such a way that the three sites are allosterically coupled (19). To analyze polyamine influence on NMDA receptor modulation by endobain $\mathrm{E}$, competitive $\left[{ }^{3} \mathrm{H}\right]$ dizocilpine binding experiments with different concentrations of SPD or endobain E were carried out. Besides, experiments with polyamine site antagonists were performed in the absence or presence of the endogenous modulator.

In the presence of SPD, endobain E decreased $\left[{ }^{3} \mathrm{H}\right]$ dizocilpine binding; however, the endogenous modulator failed to alter ligand binding potentiation by SPD. The extent of endobain $\mathrm{E}$ effect remained unaltered in the presence of a wide SPD concentration range. The concentration-response curve for endobain $\mathrm{E}$ effect was unchanged by SPD presence. Thus in neither case did SPD increase or decrease endobain E effect. Arcaine and ifenprodil are respectively competitive and noncompetitive antagonists of the polyamine site. By blocking the SPD effect on NMDA receptor, these antagonists decrease $\left[{ }^{3} \mathrm{H}\right]$ dizocilpine binding to brain membranes $(20,21)$. On assaying $\left[{ }^{3} \mathrm{H}\right]$ dizocilpine binding in the simultaneous presence of endobain $\mathrm{E}$ and arcaine or ifenprodil, additive effects were recorded. Results showed that polyamine action blockade by these antagonists failed to alter endobain $\mathrm{E}$ effect. These results suggest that endobain $\mathrm{E}$ hardly binds to the polyamine site and that receptor modulation by SPD fails to modify endobain $\mathrm{E}$ effect.

Endobain $\mathrm{E}$ and arcaine or ifenprodil were also tested at conditions that individually decreased $50 \%\left[{ }^{3} \mathrm{H}\right]$ dizocilpine binding, to observe a nonadditive effect (data not shown). This interference of endobain E effect seems unrelated to SPD site blockade. Accordingly, arcaine decreases glutamate and glycine efficacy and blocks the receptorassociated channel (22-24). Thus arcaine may well interfere with endobain E effect by decreasing receptor activation by coagonists and/or by binding to the inner channel surface. Regarding ifenprodil, it is known that both high- and low-affinity components are operative in $\left[{ }^{3} \mathrm{H}\right]$ dizocilpine binding inhibition by this antagonist, involving a specific site and the $\mathrm{Zn}^{2+}$ site, respectively (20). Therefore at high concentrations ifenprodil most likely binds to the $\mathrm{Zn}^{2+}$ site, leading to a decrease in the frequency of channel opening as well as in the time the channel remains open, most likely interfering with endobain $\mathrm{E}$ effect by reducing receptor activation by coagonists.

It should be recalled that NMDA receptor activation by glutamate and glycine favors endobain $\mathrm{E}$ effect and that antagonists for such coagonist sites interfere with endobain E effect; in support, a decrease in receptor activation by partial coagonist site blockade markedly diminished endobain $\mathrm{E}$ effect, indicating an essential requirement of receptor activation by coagonists (12). Thus, though dependent on receptor activation by glutamate and glycine, endobain E effect seems independent of receptor modulation by SPD.

In agreement with previous findings (25), present results support the contention that receptor activation by 
Reinés, Zárate, Peña, and Rodríguez de Lores Arnaiz

polyamines differs from that achieved by coagonists glutamate and glycine. Receptor activation by these coagonists enhances $\left[{ }^{3} \mathrm{H}\right]$ dizocilpine accessibility to its binding site within the receptor channel (26-28), increasing both $\left[{ }^{3} \mathrm{H}\right]$ dizocilpine association and dissociation rate constants but not ligand binding affinity at equilibrium (29). At variance, polyamines enhance $\left[{ }^{3} \mathrm{H}\right]$ dizocilpine binding at equilibrium $(21,25,30)$, an effect attributable to allosteric coupling between polyamine and ligand sites rather than an increase in $\left[{ }^{3} \mathrm{H}\right]$ dizocilpine accessibility to its binding site (21). Other lines of evidence also indicate that NMDA receptor activation by glutamate and glycine differs from that achieved by polyamines: whereas glutamate itself is able to activate the receptor, leading to channel opening, glycine and SPD fail to do so unless glutamate is also present (19).

In regard to endobain $\mathrm{E}$ chemical composition, HPLC analysis demonstrated the presence of ascorbic acid as well as that of a second $\mathrm{Na}^{+}, \mathrm{K}^{+}$-ATPase inhibitor (10); the former seems unrelated to endobain $\mathrm{E}$ effect on NMDA receptor because commercial ascorbic acid failed to modify $\left[{ }^{3} \mathrm{H}\right]$ dizocilpine binding (data not shown).

\section{SUMMARY}

Results obtained with SPD and $\mathrm{Zn}^{2+}$ support the contention that endobain $\mathrm{E}$ effect is hardly attributable to its binding on polyamine site and that this factor most likely binds inside the receptor-associated channel; although endobain E effect may be modulated according to the degree of channel activation by coagonists, it is independent of positive allosteric receptor modulation by SPD. The NMDA receptor possesses negative finetuning mechanisms that control its activity in physiological and pathological conditions (2-4). By acting as negative allosteric modulators, proton and $\mathrm{Zn}^{2+}$ decrease receptor activity by reducing channel opening. Another alternative to reduce NMDA receptor activity is to block the associated channel; on employing several compounds for this purpose, adverse events appeared as a consequence of basic neuronal function interference (2). Endobain E seems to bind to the inner channel surface, acting as a weak receptor channel blocker, so that this endogenous factor might only block the overactivated NMDA receptor. An opposite effect by endobain E leading to an increase in intracellular $\mathrm{Ca}^{2+}$ concentration as a result of $\mathrm{Na}^{+}, \mathrm{K}^{+}$-ATPase inhibition is likewise tenable; thus further experiments in other systems are expected to shed light on its final effect.

\section{ACKNOWLEDGMENTS}

G. R. de L. A and C. P. are Chief Investigator from the Consejo Nacional de Investigaciones Científicas y Técnicas (CONICET). Finantial support was provided from Agencia Nacional de Promoción Científica y Tecnológica, Universidad de Buenos Aires, and Fundación Antorchas, Argentina.

\section{REFERENCES}

1. Dingledine, R., and McBain, C. J. 1999. Glutamate and aspartate. Pages 315-333, in Siegel, G. J., Agranoff, B. W., Albers, R. W., Fisher, S. K., and Uhler, M. D. (eds.), Basic Neurochemistry, 6th ed., Lippincott-Raven Press, Philadelphia.

2. Dingledine, R., Borges, K., Bowie, D., and Traynelis, S. F. 1999. The glutamate receptor ion channels. Pharmacol. Rev. 51:7-61.

3. Mothet, J. P., Parent, A. T., Wolosker, H., Brady, R. O. Jr., Linden, D. J., Ferris, C. D., Rogawski, M. A., and Snyder, S. H. 2000. D-Serine is an endogenous ligand for the glycine site of the N-methylD-aspartate receptor. Proc. Natl. Acad. Sci. USA 97:4926-4931.

4. Stone, T. W., and Addae, J. I. 2002. The pharmacological manipulation of glutamate receptors and neuroprotection. Eur. J. Pharmacol. 447:285-296.

5. Trombley, P. Q., and Shepherd, G. M. 1996. Differential modulation by zinc and copper of amino acid receptors from rat olfactory bulb neurons. J. Neurophysiol. 76:2536-2546.

6. Fayyazuddin, A., Villarroel, A., Le Goff, A., Lerma, J., and Neyton, J. 2000. Four residues of extracellular N-terminal domain of the NR2A subunit control high-affinity $\mathrm{Zn}^{2+}$ binding to NMDA receptors. Neuron 25:683-694.

7. Rodríguez de Lores Arnaiz, G., Reinés, A., Herbin, T., and Peña, C. 1998. $\mathrm{Na}^{+}, \mathrm{K}^{+}$-ATPase interaction with a brain endogenous inhibitor (endobain E). Neurochem. Int. 33:425-433.

8. Vatta, M., Peña, C., Fernández, B., and Rodríguez de Lores Arnaiz, G. 1999. A brain $\mathrm{Na}^{+}, \mathrm{K}^{+}$-ATPase inhibitor (endobain E) enhances norepinephrine release in rat hypothalamus. Neuroscience 90 : 573-579.

9. Rodríguez de Lores Arnaiz, G., and Peña, C. 1995. Characterization of synaptosomal membrane $\mathrm{Na}^{+}, \mathrm{K}^{+}$-ATPase inhibitors. Neurochem. Int. 27:319-327.

10. Rodríguez de Lores Arnaiz, G., Herbin, T., and Peña, C. 2003. A comparative study between a brain $\mathrm{Na}^{+}, \mathrm{K}^{+}$-ATPase inhibitor (endobain E) and ascorbic acid. Neurochem. Res. 28:903-910.

11. Reinés, A., Peña, C., and Rodríguez de Lores Arnaiz, G. 2001. $\left[{ }^{3} \mathrm{H}\right]$ Dizocilpine binding to N-methyl-D-aspartate (NMDA) receptor is modulated by an endogenous $\mathrm{Na}^{+}, \mathrm{K}^{+}$-ATPase inhibitor: Comparison with ouabain. Neurochem. Int. 39:301-310.

12. Reinés, A., Peña, C., and Rodríguez de Lores Arnaiz, G. 2001. NMDA receptor activation favours its allosteric modulation by an endogenous $\mathrm{Na}^{+}, \mathrm{K}^{+}$-ATPase inhibitor. J. Neurochem. 78:(Suppl.1) BP18-BP44. (Abstract)

13. Ogita, K., and Yoneda, Y. 1999. Signal transduction through ion channels associated with excitatory amino acid receptors. Methods Enzymol. 294:385-410.

14. Yoneda, Y., Ogita, K., and Enomoto, R. 1991. Characterization of spermidine-dependent $\left[{ }^{3} \mathrm{H}\right](+)$-5-methyl-10,11-dihydro-5Hdibenzo[a,d]cyclohepten-5,10-imine (MK-801) binding in brain synaptic membranes treated with Triton X-100. J. Pharmacol. Exp. Ther. 256:1161-1172.

15. Rodríguez de Lores Arnaiz, G., and Antonelli de Gómez de Lima, M., 1986. Partial characterization of an endogenous factor which modulates the effect of catecholamines on synaptosomal $\mathrm{Na}^{+}, \mathrm{K}^{+}$-ATPase. Neurochem. Res. 11:933-947.

16. Cowburn, R. F., Wiehager, B., Trief, E., Li-Li, M., and Sundström, E. 1997. Effects of $\beta$-amyloid-(25-35) peptide on radioligand 
binding to excitatory amino acid receptor and voltage-dependent calcium channels: Evidence for a selective affinity for the glutamate and glycine recognition sites of NMDA receptor. Neurochem. Res. 22:1437-1442.

17. Lowry, O. H., Rosebrough, N. J., Farr, A. L., and Randall, R. J. 1951. Protein measurement with the Folin phenol reagent. J. Biol. Chem. 193:265-275

18. Christine, C. W., and Choi, D. W. 1990. Effect of Zinc on NMDA receptor-mediated channel currents in cortical neurons. J. Neurosci. 10:108-116.

19. Ransom, R. W., and Stec, N. L. 1988. Cooperative modulation of $\left[{ }^{3} \mathrm{H}\right] \mathrm{MK}-801$ binding to the N-methyl-D-aspartate receptor-ion channel complex by L-glutamate, glycine, and polyamines. J. Neurochem. $51: 830-836$

20. Reynolds, I. J., and Miller, R. J. 1989. Ifenprodil is a novel type of N-Methyl-D-aspartate receptor antagonist: Interaction with polyamines. Mol. Pharmacol. 36:758-765.

21. Reynolds, I. J. 1990. Arcaine uncovers dual interaction of polyamines with the N-methyl-D-aspartate receptor. J. Pharmacol. Exp. Ther. 255:1001-1007.

22. Sacaan, A. I., and Johnson, K. M. 1990. Competitive inhibition of magnesium induced $\left[{ }^{3} \mathrm{H}\right] \mathrm{N}-(1-[$ thienyl]cyclohexyl)piperidine binding by arcaine: Evidence for a shared spermidine-magnesium binding site. Mol. Pharmacol. 38:705-710.

23. Donevan, S. D., Jones, S. M., and Rogawski, M. A. 1992. Arcaine blocks N-methyl-D-aspartate receptor responses by an open channel mechanism: Whole-cell and single-channel recording studies in cultured hippocampal neurons. Mol. Pharmacol. 41:727-735.
24. Rock, D. M., and MacDonald, R. L. 1992. Spermine and related polyamines produce a voltage-dependent reduction of N-methylD-aspartate receptor single-channel conductance. Mol. Pharmacol. 42:157-164.

25. Reynolds, I. J. 1992. 1,5-(Diethylamino)piperidine, a novel spermidine analogue that more specifically activates the N-methylD-aspartate receptor-associated polyamine site. Mol. Pharmacol. 41:989-992.

26. Bonhaus, D. W., and McNamara, J. O. 1988. N-methylD-aspartate receptor regulation of uncompetitive antagonist binding in rat brain membranes: Kinetic analysis. Mol. Pharmacol. $34: 250-255$.

27. Kloog, Y., Haring, R., and Sokolovsky, M. 1988. Kinetic characterization of the phencyclidine-N-methyl-D-aspartate receptor interaction: Evidence for a steric blockade of the channel. Biochemistry $27: 843-848$.

28. Reynolds, I. J., and Miller, R. J. 1988. Multiple sites for the regulation of the N-methyl-D-aspartate receptor. Mol. Pharmacol 33:581-584

29. Yoneda, Y., Ogita, K., Kouda, T., and Ogawa, Y. 1990. Radioligand labeling of N-methyl-D-aspartic acid (NMDA) receptors by $\left[{ }^{3} \mathrm{H}\right]( \pm$ )-3-(2-carboxypiperazin-4-yl)phosphonic acid in brain synaptic membrane treated with Triton X-100. Biochem. Pharmacol. 39:225-228.

30. Williams, K., Dawson, V. L., Romano, C., Dichter, M. A., and Molinoff, P. B. 1990. Characterization of polyamines having agonist, antagonist and inverse agonist effect at the polyamine recognition site of the NMDA receptor. Neuron 5:199-208. 